Lipid levels in AS and PsA pts through Wk 208

\begin{tabular}{|c|c|c|c|c|c|c|}
\hline \multirow{2}{*}{$\begin{array}{l}\text { Parameters } \\
\text { (Normal } \\
{\text { level }{ }^{5} \text { ) }}\end{array}$} & \multirow[t]{2}{*}{ Wk } & \multicolumn{2}{|c|}{ AS } & \multicolumn{3}{|c|}{ PsA } \\
\hline & & $\begin{array}{l}\text { SEC } 150 \\
\mathrm{mg} \\
(\mathrm{N}=504)\end{array}$ & $\begin{array}{c}\text { PBO } \\
(\mathrm{N}=388)\end{array}$ & $\begin{array}{l}\text { SEC } 300 \mathrm{mg} \\
\quad(\mathrm{N}=461)\end{array}$ & $\begin{array}{l}\text { SEC } 150 \mathrm{mg} \\
(\mathrm{N}=907)\end{array}$ & $\begin{array}{c}\text { PBO } \\
(\mathrm{N}=681)\end{array}$ \\
\hline \multirow[t]{4}{*}{$\begin{array}{l}\text { TC } \\
(<5.2)^{*}\end{array}$} & BL & $\begin{array}{l}4.92 \\
(502)\end{array}$ & $\begin{array}{l}4.90 \\
(387)\end{array}$ & $4.99(459)$ & $5.07(905)$ & $\begin{array}{l}5.12 \\
(675)\end{array}$ \\
\hline & 16 & $\begin{array}{c}5.03 \\
(486)\end{array}$ & $\begin{array}{c}4.87 \\
(362)\end{array}$ & $5.08(448)$ & $5.14(879)$ & $\begin{array}{l}5.03 \\
(634)\end{array}$ \\
\hline & 104 & $\begin{array}{l}4.91 \\
(390)\end{array}$ & & $5.02(199)$ & $5.13(350)$ & \\
\hline & 208 & $\begin{array}{l}4.91 \\
(135)\end{array}$ & & $4.88(74)$ & $5.06(72)$ & \\
\hline \multirow[t]{4}{*}{$\begin{array}{l}\text { TG fasting } \\
(<1.7)^{*}\end{array}$} & BL & $\begin{array}{r}1.29 \\
(502)\end{array}$ & $\begin{array}{l}1.31 \\
(387)\end{array}$ & $1.48(460)$ & $1.53(905)$ & $\begin{array}{l}1.59 \\
(675)\end{array}$ \\
\hline & 16 & $\begin{array}{c}1.40 \\
(486)\end{array}$ & $\begin{array}{c}1.31 \\
(362)\end{array}$ & $1.62(448)$ & $1.64(879)$ & $\begin{array}{l}1.54 \\
(634)\end{array}$ \\
\hline & 104 & $\begin{array}{c}1.42 \\
(390)\end{array}$ & & $1.61(199)$ & $1.60(350)$ & \\
\hline & 208 & $\begin{array}{c}1.44 \\
(136)\end{array}$ & & $1.66(74)$ & $1.67(72)$ & \\
\hline \multirow[t]{4}{*}{$\begin{array}{l}\text { LDL-C } \\
(<2.6)^{*}\end{array}$} & BL & $\begin{array}{l}3.09 \\
(502)\end{array}$ & $\begin{array}{l}3.08 \\
(387)\end{array}$ & $3.11(460)$ & $3.18(905)$ & $\begin{array}{c}3.17 \\
(675)\end{array}$ \\
\hline & 16 & $\begin{array}{c}3.12 \\
(486)\end{array}$ & $\begin{array}{c}3.02 \\
(362)\end{array}$ & $3.16(448)$ & 3.20 (879) & $\begin{array}{l}3.11 \\
(634)\end{array}$ \\
\hline & 104 & $\begin{array}{c}3.08 \\
(390)\end{array}$ & & 3.15 (199) & $3.24(350)$ & \\
\hline & 208 & $\begin{array}{l}3.08 \\
(135)\end{array}$ & & $3.03(74)$ & $3.24(72)$ & \\
\hline \multirow[t]{4}{*}{$\begin{array}{l}\text { HDL-C } \\
(>1.5)^{*}\end{array}$} & BL & $\begin{array}{c}1.44 \\
(502)\end{array}$ & $\begin{array}{l}1.43 \\
(387)\end{array}$ & $1.43(460)$ & $1.44(905)$ & $\begin{array}{l}1.47 \\
(675)\end{array}$ \\
\hline & 16 & $\begin{array}{c}1.46 \\
(486)\end{array}$ & $\begin{array}{c}1.43 \\
(362)\end{array}$ & $1.43(448)$ & $1.45(879)$ & $\begin{array}{c}1.43 \\
(634)\end{array}$ \\
\hline & 104 & $\begin{array}{l}1.47 \\
(390)\end{array}$ & & $1.40(199)$ & $1.49(350)$ & \\
\hline & 208 & $\begin{array}{c}1.41 \\
(135)\end{array}$ & & $1.42(74)$ & $1.38(72)$ & \\
\hline \multirow[t]{4}{*}{$\begin{array}{l}\text { TC/HDL-C } \\
\text { ratio }\end{array}$} & BL & $\begin{array}{l}3.67 \\
(502)\end{array}$ & $\begin{array}{l}3.68 \\
(387)\end{array}$ & $3.72(459)$ & 3.79 (905) & $\begin{array}{l}3.75 \\
(675)\end{array}$ \\
\hline & 16 & $\begin{array}{c}3.72 \\
(486)\end{array}$ & $\begin{array}{l}3.61 \\
(362)\end{array}$ & $3.81(448)$ & 3.88 (879) & $\begin{array}{l}3.77 \\
(634)\end{array}$ \\
\hline & 104 & $\begin{array}{l}3.58 \\
(390)\end{array}$ & & $3.82(199)$ & $3.76(350)$ & \\
\hline & 208 & $\begin{array}{c}3.72 \\
(135)\end{array}$ & & $3.69(74)$ & 3.94 (72) & \\
\hline
\end{tabular}

${ }^{*} \mathrm{mmol} / \mathrm{L}$ (n). ${ }^{5}$ https://optimalhealthsolutions.ca/cholesterol-ratio/

\section{FRI0402 1 SECUKINUMAB FOR AXIAL SPONDYLOARTHRITIS: DRUG SURVIVAL IN REAL-WORLD SETTING AND RESPONSE FACTORS}

Carolina Merino Argumánez ${ }^{1}$, Valentina Emperiale ${ }^{2}$, María Martín ${ }^{3}$, Marta Valero ${ }^{4}$, Javier Bachiller-Corral ${ }^{4}$, Beatriz Joven-lbáñez ${ }^{5}$, Ana Pérez Gómez ${ }^{6}$, Jose Campos Esteban'. ${ }^{1}$ Hospital Puerta de Hierro, Majadahonda (Madrid), Spain; ${ }^{2}$ Hospital Príncipe Asturias, Alcalá de Henares, Spain; ${ }^{3}$ Hospital Doce de octubre, Madrid, Spain; ${ }^{4}$ Hospital Ramón y Cajal, Madrid, Spain; ${ }^{5}$ Hospital Doce de Octubre, Madrid, Spain; ${ }^{6}$ Hospital Príncipe Asturias, Alcalá de Henares, Spain

Background: IL-17 inhibition has been proved effective in patients with ankylosing spondylitis (AS) in clinical trials and it has been added to the most recent national and international treatment guidelines. However, realworld data of its use is still scarce.

Objectives: This study aims to analyze drug survival of secukinumab for axial spondyloarthritis $(\mathrm{AxSpA})$ in a real world setting and identify response factors.

Methods: Multicentric observational, retrospective, longitudinal study conducted in 4 tertiary hospitals of the Madrid region. Patients over 18 y.o. with clinical diagnosis of AxSpa and having received at least one dose of secukinumab between January 2016 and October 2018 were included. Medical records were reviewed to collect demographic and clinical data related to AxSpA, its features and treatment. Statistical analysis was performed including bivariate analisys (considering withdrawal of drug during study period or not) and survival analysis with Kaplan-Meier and Cox regression. Reasons for discontinuating therapy are described. To detect inffluential variables, demographic characteristics, HLA-B27 positivity, radiographic features, previous biologic therapies, comorbidities and extra-articular involvement were analyzed.

Results: Out of 143 patients included, 89 (62\%) mantained secukinumab therapy at the end of the observation period (Dec 31, 2018), with an average drug survival time of $17 \pm 8,2$ months. 54 patients $(38 \%)$ withdrawn therapy, due to primary ineffectiveness (26), secundary ineffectiveness (14), adverse events (7) and other reasons (7). Median time to withdrawal was 6 months $(0-21)$. No significative differences were found between groups, but a tendency to higher number of female patients (55\% vs $41 \%$, p 0,07), non radiographic AxSpA (35\% vs $27 \%$, p 0,053 ) and lower HLA-B27 positivity $(50 \%$ vs $65 \%$, p 0,052$)$ was noted in the group withdrawing therapy. Previous exposure to biologic therapy did not differ $(75 \%$ vs $71 \%$, p 0,37). Number of bDMARDs before Secukinumab therapy was also similar in both groups; the proportion of patients with previous exposure to 2 or more bDMARDs were $17 \%$ vs $22 \%$ (p 0.373). Neither differences were found in all other variables studied (demographic, hip arthropathy, syndesmophytes, extra-articular involvement -uveitis, psoriasis, inflammatory bowel disease- nor in comorbidities (tobacco exposure, hypertension, diabetes mellitus, dyslipidemia, ischemic heart disease malignancy)

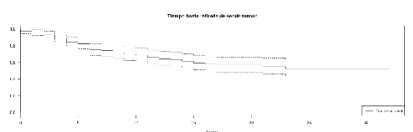

Conclusion: This study assesing drug survival of secukinumab in realworld setting showed a trend to lower drug survival in comparison to clinical trial data. No differences were found in the treatment withdrawal group. Population in which secukinumab is prescribed in real-world setting differs from clinical trials, with higher previous exposure to bDMARDs and higher comorbidity.

Disclosure of Interests: Carolina Merino Argumánez: None declared, Valentina Emperiale: None declared, María Martín: None declared, Marta Valero: None declared, Javier Bachiller-Corral: None declared, Beatriz Joven-lbáñez Speakers bureau: Celgene, Novartis, MSD, Pfizer, AbbVie, and Janssen, Ana Pérez Gómez: None declared, Jose Campos Esteban: None declared

DOI: 10.1136/annrheumdis-2019-eular.7874

\section{FRI0403 HIGH BASELINE PATIENT'S COMPARED WITH EVALUATOR'S GLOBAL ASSESSMENT IS ASSOCIATED WITH LOWER RETENTION AND REMISSION RATES OF FIRST TNF INHIBITOR IN AXSPA PATIENTS - DATA FROM THE EUROSPA COLLABORATION}

Brigitte Michelsen, Lykke Ørnbjerg, Anne Gitte Loft, Joseph Sexton, Adrian Ciurea, Heřman Mann, Kari Eklund, Ayten Yazici, Maria Jose Santos, Johan Askling, Ziga Rotar, Björn Gudbjornsson, Manuel Pombo-Suarez, Catalin Codreanu, Irene van der Horst-Bruinsma, Eirik Kristianslund, Michael Nissen, Karel Pavelka, Nina Trokovic, Nevsun Inanc, Elsa Vieira-Sousa, Daniela DI Giuseppe, Matija Tomsic, Arni Jon Geirsson, Ruxandra lonescu, Marleen van de Sande, Florenzo lannone, Carlos Sánchez-Piedra, Gareth T. Jones, Lise Hyldstrup, Niels Steen Krogh, Merete L. Hetland, Mikkel Ǿstergaard. EuroSpA Research Collaboration, on behalf of DANBIO (Denmark), ARTIS (Sweden), SCQM (Switzerland), NOR-DMARD (Norway), ATTRA (Czech Republic), Reuma.pt (Portugal), BIOBADASER (Spain), ROB-FIN (Finland), biorx.si (Slovenia), ICEBIO (Iceland), TURKBIO (Turkey), RRBR (Romania), ARC (Netherlands), BSRBR-AS (UK), GISEA (Italy), Denmark

Background: Discordance between baseline patient's and evaluator's global assessment of disease activity is common. ${ }^{1}$ However, the impact of such discordance on retention and remission rates of TNF inhibitor (TNFi) therapy in axial spondyloarthritis (axSpA) patients remains unexplored

Objectives: To assess the impact of baseline discordance, defined as "patient's minus evaluator's global assessment of disease activity" ( $\triangle P E G$ ), on retention and remission rates of first TNFi in female and male axSpA patients across Europe.

Methods: AxSpA patients from 10 European registries participating in the European Spondyloarthritis Research Network Collaboration (EuroSpA) were included. Retention rates after 6/12/24 months' treatment with first TNFi were assessed with Kaplan-Meier analyses, with comparison between baseline $\triangle \mathrm{PEG}$ quartiles with log rank test, stratified by gender. Proportions of patients in BASDAI remission $(\leq 2)$ and ASDAS inactive disease $(<1.3)$ after 6/12/24 months for different $\triangle P E G$ quartiles were compared with Chi-square test, stratified by gender.

Results: A total of 9013 axSpA patients were included. Mean(SD) age for women $(n=3639) / \operatorname{men}(n=5374)$ were $42.7(12.0) / 41.7(12.0)$ years, disease duration $5.1(7.4) / 6.9(8.7)$ years, median(25-75 percentiles) baseline $\triangle P E G$ 